\title{
Pelatihan pembuatan minuman berserat alami dari buah nanas dan nata de coco
}

\author{
Aisyah Hadi Ramadani ${ }^{\text {* }}$, Reny Rosalina ${ }^{1}$, Riska Surya Ningrum ${ }^{2}$ \\ ${ }^{1}$ Institut Ilmu Kesehatan Bhakti Wiyata Kediri. Jl. Wahid Hasyim No. 65, Kota Kediri, 64114, Indonesia \\ ${ }^{2}$ Lembaga Ilmu Pengatahuan Indonesia. Jl. Raya Bogor Km.46 Cibinong, Bogor, 16911, Indonesia \\ * Corresponding author. Email: aisyahramadani47@gmail.com
}

Received: 10 June 2020; Revised: 24 September 2020; Accepted: 27 September 2020

\begin{abstract}
Abstrak: Salah satu sentra produksi nanas di Jawa Timur adalah di Dusun Puhrejo, Kecamatan Ngancar, Kabupaten Kediri. Nanas yang dihasilkan dijual dalam bentuk buah segar dan olahan, contohnya adalah sari nanas. Kualitas produk olahan sari nanas masih kurang maksimal sehingga pada kegiatan ini diberikan pengetahuan dan pelatihan tentang cara pengolahan buah nanas dalam bentuk minuman berserat. Minuman berserat dibuat dari campuran buah nanas yang kaya nutrisi dan nata de coco yang mengandung serat alami. Penambahan nata de coco juga berfungsi sebagai penstabil (emulsifier) agar produk minuman yang dihasilkan memiliki mutu yang lebih baik dan daya simpan yang lebih lama. Terdapat 2 tahapan kegiatan yang diikuti oleh 25 warga Dusun Puhrejo, yaitu penyuluhan dan pelatihan. Hasil yang diperoleh dari kegiatan ini adalah adanya peningkatan pengetahuan peserta mengenai pemanfaatan dan cara pengolahan nanas yang tepat sehingga tidak mengurangi kandungan gizi di dalamnya. Minat peserta untuk mengembangkan produk olahan nanas juga meningkat karena produk yang dihasilkan dapat memberi nilai tambah buah nanas. Produk olahan yang diperoleh dari kegiatan ini juga dijadikan produk unggulan UMKM Dusun Puhrejo.
\end{abstract}

Kata Kunci: nanas, nata de coco, pasteurisasi, pelatihan, UMKM

\section{Training on produce a healthy beverage from pineapple fruits and nata de coco}

Abstract: One of the pineapple production centers in East Java is in Puhrejo village, Ngancar, Kediri. The pineapple was sold in the fresh and processing fruits, like pineapple juice. But the pineapple juice has low quality so this activity gave information and training about how to process pineapple to be a healthy beverage product. A healthy beverage produced from pineapple that contains many nutritions and nata de coco that contain natural fiber. The aim of addition nata de coco is as emulsifier therefore the beverage obtained from this project has a better quality and longer shelf life. The activity was attended by 25 Puhrejo village residents and used two steps, that are counseling and training. The result of the activity is an increase in the community's knowledge about the potential of pineapple and the right processing of it so the nutrition did not decrease. The desire of the community to process pineapple into a variety of products also increased because that product can provide added value to pineapple. The healthy beverage product from this activity will be a superior product from UMKM of Puhrejo village.

Keywords: nata de coco, pineapple, pasteurization, training, UMKM

How to Cite: Ramadani, A., Rosalina, R., \& Ningrum, R. (2020). Pelatihan pembuatan minuman berserat alami dari buah nanas dan nata de coco. JPPM (Jurnal Pendidikan dan Pemberdayaan Masyarakat), 7(2), 147-158. doi:https://doi.org/10.21831/jppm.v7i2.32162 


\section{JPPM (Jurnal Pendidikan dan Pemberdayaan Masyarakat), 7 (2), 2020 - 148}

Aisyah Hadi Ramadani, Reny Rosalina, Riska Surya Ningrum

\section{PENDAHULUAN}

Jawa Timur merupakan salah satu penghasil nanas terbesar di Indonesia, dengan total produksi 171.304 ton pada tahun 2015 (BPS, 2015). Salah satu sentra produksi nanas di Jawa Timur adalah Kabupaten Kediri, tepatnya di Kecamatan Ngancar. Pada tahun 2011, produksi nanas di Kecamatan Ngancar mencapai 250 ton per minggu (Dinas Pertanian Kabupaten Kediri, 2015). Salah satu dusun di Kecamatan Ngancar yang masyarakatnya aktif mengikuti pelatihan budidaya dan pengolahan nanas adalah Dusun Puhrejo. Dusun Puhrejo memiliki lahan nanas seluas 2\% dari total keseluruhan perkebunan nanas di wilayah Ngancar (BPS, 2014).

Di daerah Ngancar, penjualan buah nanas dapat berupa buah segar ataupun produk olahan, seperti selai, dodol, nanas kaleng, manisan, dan sari buah. Akan tetapi, kuantitas dan kualitas produk olahan nanas yang diperjualbelikan tergolong masih rendah. Contohnya, sari nanas yang beredar di daerah wisata Gunung Kelud memiliki kemasan yang kurang menarik, rasanya yang terkadang sangat masam atau sedikit pahit, dan tidak tahan lama (hanya bertahan \pm 1 hari). Hal tersebut menyebabkan penjualan sari nanas tidak maksimal dan pedagang tidak memperoleh keuntungan yang menjanjikan. Padahal jika dapat membuat sari nanas dengan kualitas yang baik maka produk sari nanas tersebut dapat dijadikan oleh-oleh khas Kediri. Terlebih lagi jika dipasarkan di daerah wisata seperti Gunung Kelud, dimana umumnya pengunjung akan mencari dan membeli oleh-oleh khas daerah tersebut.

Nanas merupakan buah yang kaya akan vitamin, mineral, dan senyawa bioaktif (Hossain et al., 2015; Jenitha X \& Anusuya A, 2016) yang dapat meningkatkan kesehatan dan daya tahan tubuh sedangkan nata de coco mengandung serat yang cukup tinggi sehingga dapat dimanfaatkan sebagai dietary fiber (serat diet). Kombinasi antara sari nanas dengan nata de coco akan menghasilkan minuman sehat dan berserat.

Oleh karena itu kegiatan pengabdian kepada masyarakat ini bertujuan untuk meningkatkan pengetahuan masyarakat tentang pembuatan minuman berserat alami dari buah nanas dan nata de coco. Selain itu juga untuk memotivasi masyarakat agar berkreasi dan berinovasi dalam menciptakan produk-produk unggulan melalui pengolahan hasil perkebunan daerah sehingga dapat mewujudkan kemandirian ekonomi masyarakat.

\section{METODE}

Pelaksanaan program pengabdian masyarakat ini dilakukan dengan metode participatory action research (PAR) yang merujuk model Kemmis dan Mc Taggart (1988). Menurut Saugi dan Sumarno (2015) dengan PAR masyarakatlah yang berperan besar dan terlibat secara langsung dalam setiap proses pelaksanaan program. Komponen dalam PAR terdiri dari perencanaan, tindakan, dan refleksi.

Tahap perencanaan dilaksanakan dalam bentuk survei lokasi untuk mendata potensi daerah, social engagement dan focus group discussion (FGD) kepada kelompok-kelompok target program yaitu kelompok tani, PKK, dan karang taruna dusun Puhrejo. Pada tahap ini masalah dan keinginan dari kelompok dapat tergali dengan maksimal dan disusun solusi bersama. Teknik ini memungkinkan peran serta penuh dari masyarakat untuk menyelesaikan masalah setempat (Rahmat \& Mirnawati, 2020).

Tahap tindakan merupakan proses eksekusi problem solving yang telah disepakati dalam tahapan perencanaan. Tahap ini dilakukan melalui 2 tahapan kegiatan, yaitu penyuluhan dan pelatihan. Tujuan dari proses penyuluhan adalah memberikan edukasi atau pengetahuan kepada masyarakat tentang hal-hal yang terkait dengan pengolahan nanas menjadi produk yang memiliki nilai ekonomi yang lebih tinggi. Proses penyuluhan dilakukan oleh 2 narasumber, yaitu dari Lembaga Ilmu Pengetahuan Indonesia (LIPI) sebagai narasumber pertama dan Dinas Koperasi dan UMKM Kapubaten Kediri sebagai narasumber kedua.

Narasumber pertama menyampaikan materi mengenai: (1) Keistimewaan buah nanas dan nata de coco berdasarkan kandungan senyawa di dalamnya; (2) Pentingnya mengolah buah nanas menjadi produk yang memiliki nilai ekonomi lebih tinggi; (3) Produk olahan buah nanas 
JPPM (Jurnal Pendidikan dan Pemberdayaan Masyarakat), 7 (2), 2020 - 149

Aisyah Hadi Ramadani, Reny Rosalina, Riska Surya Ningrum

beserta kualitasnya yang sudah ada di daerah Ngancar; (4) Cara membuat jus nanas yang memiliki kualitas yang baik (nutrisi yang tetap terjaga) dan masa simpan yang lama tanpa harus menambahkan pengawet buatan (sintetis) pada jus nanas tersebut; (5) Cara membuat produk olahan yang dihasilkan menjadi lebih menarik; (6) Perhitungan tekno ekonomi untuk mengetahui modal yang dibutuhkan untuk proses produksi, harga penjualan produk, dan keuntungan yang dapat diperoleh.

Narasumber kedua membahas mengenai: (1) Kelengkapan yang harus dipenuhi oleh UMKM sebelum memasarkan produknya, seperti ijin usaha (PIRT); (2) Cara pengurusan PIRT; (3) Pentingnya inovasi yang berkelanjutan yang harus dilakukan oleh UMKM agar produknya tetap dapat bersaing di pasaran; dan (4) Peran pemerintah kabupaten dalam mendukung pemasaran produk khas Kabupaten Kediri, khususnya UMKM Dusun Puhrejo.

Kegiatan pelatihan pembuatan minuman berserat alami dari buah nanas dan nata de coco ini diikuti oleh 25 orang peserta, meliputi ibu-ibu PKK, kelompok tani, dan karang taruna Dusun Puhrejo. Pada akhir program dilakukan refleksi dengan tujuan menilai ketercapaian target dan penginventarisasian hambatan aktivitas selama program berjalan. Tingkat pencapaian target dan keberhasilan kegiatan diukur menggunakan kuisioner yang dibagikan sebelum dan sesudah kegiatan dilakukan. Tahap ini untuk mengetahui ada tidaknya perubahan dalam kelompok objek (Rahmat \& Mirnawati, 2020).

\section{HASIL DAN PEMBAHASAN}

\section{Proses perencanaan}

Analisa kondisi lingkungan dusun Puhrejo diperoleh data bahwa kawasan ini memiliki potensi sumber daya perkebunan nanas yang luas sekitar 64 ha (Ramadani et al., 2019). Masalah dan solusi yang tergali dari FGD dengan kelompok target antara lain: (1) Masyarakat Puherjo hanya sebagai buruh tani pada perkebunan nanas yang ada, sehingga mereka perlu alternative income; (2) Belum banyak variasi produk olahan nanas padahal potensi panen besar; (3) Kualitas produk olahan nanas yang sudah ada sangat rendah terutama pada lama daya tahan produk sehingga perlu adanya inovasi pengawetan yang tepat dan maksimal; (4) pengetahuan masyarakat terhadap metode marketing dan promosi yang masih rendah.

Partisipasi masyarakat telah terlihat maksimal dalam proses perencanaan ini. Salah satunya dalam bentuk inisiasi untuk membagi peran dan tugas tiap kelompok dalam aktivitas program. Rincian pembagian tugas tersebut seperti tertera pada Tabel 1.

Tabel 1. Pembagian peran dalam kegiatan produksi minuman jus nanas

\begin{tabular}{ll}
\hline Kelompok & \multicolumn{1}{c}{ Peran } \\
\hline Kelompok & Kelompok tani di dusun Puhrejo berperan sebagai penyuplai bahan baku buah nanas \\
tani & yang digunakan sebagai jus \\
PKK & Kelompook PKK bertanggung jawab pada proses produksi minuman jus nanas hingga \\
& pengemasan pada botol-botol dan pelabelan \\
Karang & Karang taruna Puhrejo yang beranggota pemuda mengisi peran pada promosi dan \\
taruna & pemasaran produk
\end{tabular}

Pemberdayaan kelompok PKK yang beranggotakan ibu-ibu memberikan dampak pengembangan dan terbentuknya konsep diri yang kuat untuk berdaya mandiri secara ekonomi. Alasan pelibatan kelompok perempuan pada program ini karena memiliki modal sosial yang kuat untuk bekerja sama membangan keprcayaan social dan jaringan social yang luas (Harianti \& Tanberika, 2018; Nugroho, 2017).

\section{Proses penyuluhan}

Metode yang digunakan untuk mencapai target kegiatan yang telah ditentukan, yaitu melalui penyuluhan dan pelatihan. Proses penyuluhan dilakukan oleh 2 pemateri, yaitu dari Lembaga Ilmu Pengetahuan Indonesia (LIPI) dan Dinas Koperasi dan UMKM Kapubaten Kediri. 
JPPM (Jurnal Pendidikan dan Pemberdayaan Masyarakat), 7 (2), 2020 - 150

Aisyah Hadi Ramadani, Reny Rosalina, Riska Surya Ningrum

Pemateri pertama yang berasal dari LIPI menyampaikan tentang kandungan gizi buah nanas, berbagai macam produk olahan yang dapat dibuat dari buah nanas, inovasi minuman berserat alami dari nanas dan nata de coco beserta kelebihannya, cara pengolahan dan pengemasan yang tepat sehingga produk minuman yang dihasilkan tetap memiliki kandungan gizi yang dibutuhkan oleh tubuh serta memiliki masa simpan yang panjang. Pemateri kedua menyampaikan perihal tata cara perijinan dan pemasaran produk yang mereka hasilkan. Hal ini sangat penting untuk diketahui masyarakat, mengingat banyaknya masyarakat yang kesulitan untuk mengurus perijinan produk UMKM mereka. Forum ini juga dapat menjadi jembatan antara pemerintah kabupaten dan masyarakat dalam mengembangkan dan mempromosikan produk UMKM berbasis produk olahan hasil perkebunan daerah.

\section{Proses pelatihan pembuatan minuman berserat}

Proses pelatihan dilakukan dengan mendemonstrasikan cara pembuatan minuman berserat alami dari buah nanas dan nata de coco. Buah nanas yang digunakan dalam proses pembuatan minuman berserat alami ini tidak boleh yang berkualitas rendah (busuk) karena akan mempengaruhi rasa, aroma, dan masa simpan produk. Alur pembuatan minuman berserat alami dari buah nanas dan nata de coco dapat dilihat pada Gambar 1.

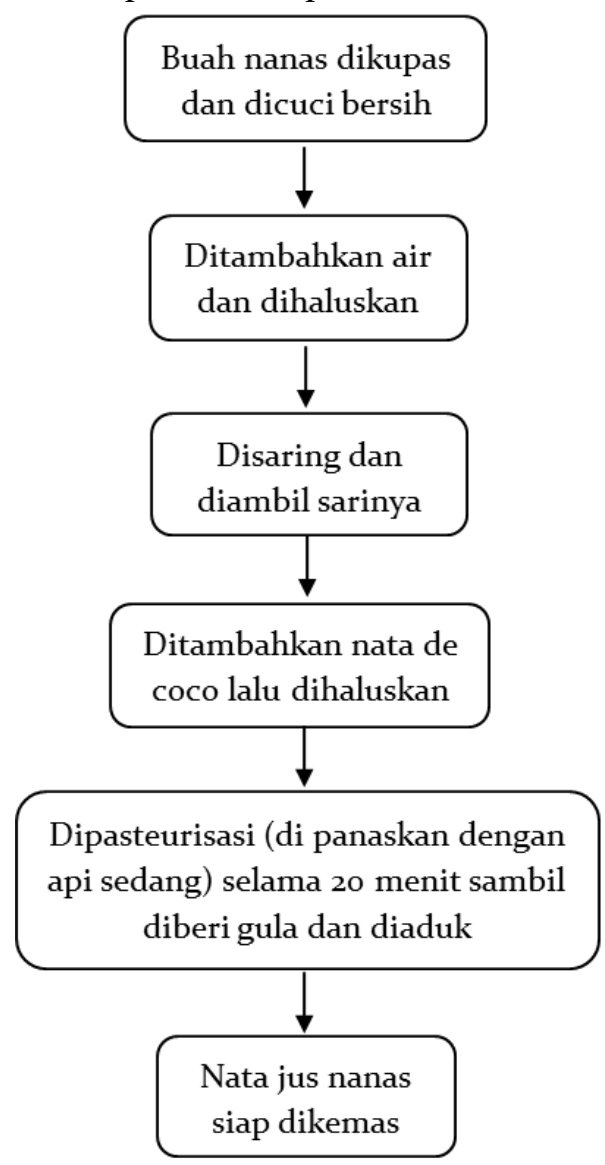

Gambar 1. Skema pembuatan minuman berserat alami dari buah nanas dan nata de coco

Buah nanas merupakan buah yang kaya nutrisi, seperti vitamin (B1, B2, B3, B6, dan C), mineral (besi, kalsium, fosfor, seng, kalium, dan magnesium), serat, protein, karbohidrat, kalori, dan enzim bromelin (Hossain et al., 2015). Selain itu buah nanas juga memiliki kandungan senyawa bioaktif seperti fenolik, steroid, flavonoid, terpenoid, saponin, quinine, kumarin, karbohidrat, glikosida, alkaloid, dan tannin (Jenitha X \& Anusuya A, 2016). Konsumsi sari buah nanas atau jus nanas dapat meningkatkan daya tahan tubuh, menghambat penuaan dini, dan terhindar dari berbagai macam penyakit karena kandungan senyawa aktif di dalam nanas yang 
JPPM (Jurnal Pendidikan dan Pemberdayaan Masyarakat), 7 (2), 2020 - 151

Aisyah Hadi Ramadani, Reny Rosalina, Riska Surya Ningrum

bersifat sebagai antioksidan (Kaushik \& Kundu, 2018), antibakteri (Bhagavanthy et al., 2019), dan antivirus (Andjaitan, et al., 2018).

Nata de coco merupakan lapisan selulosa yang terbentuk dari hasil aktivitas bakteri Acetobacter xylinum di dalam media fermentasi (substrat) air kelapa (Halib et al., 2012). Nata de coco berwarna putih, kenyal, tidak larut dalam air, dan memiliki kandungan serat yang cukup tinggi sehingga dapat digunakan sebagai serat alami atau serat pangan (dietary fiber). Nata de coco juga dapat digolongkan sebagai prebiotik karena mengandung protein yang berasal dari bakteri A.xylinum yang terperangkap diantara benang-benang selulosa (Setiaji et al., 2010). Secara kuantitatif, kandungan serat pada nata de coco adalah 1,91\% (Santosa et al., 2020), protein o, $45 \%$, kadar abu 0,35\%, kadar air 95\%, serta beberapa senyawa bioaktif seperti benzeneacetic acid, hexadecanoid acid, 22-hydroxyhopane, tetradecanoic acid, 9-octadecanoic acid, p-cresol, 9-octadecenamide, pentadecanoic acid, heptadecanecarboxylic acid, dan phenol 4-2-aminoethyl (Anam et al., 2019). Tubuh membutuhkan serat alami untuk membantu proses pencernaan di usus halus dan proses penyerapan air di usus besar. Kekurangan serat dapat mengakibatkan sembelit dan sulit buang air besar.

Nata atau yang lebih dikenal dengan nama bacterial cellulose merupakan selulosa yang dihasilkan oleh bakteri A.xylinum. Selulosa tersebut adalah salah satu sumber hidrokoloid yang dapat berfungsi sebagai penstabil (emulsifier) pada produk pangan (Sukara \& Meliawati, 2014). Hidrokoloid merupakan suatu polimer yang mampu menyerap air dengan mudah dan membentuk gel. Pada pembentukan gel, terjadi reaksi ikatan silang antar rantai polimer sehingga membentuk struktur heliks (Herawati, 2018). Struktur tersebut dapat mempengaruhi karakteristik gel, seperti kelarutan, viskositas, keelastisitasan, dan kekuatan gel. Karakteristik hidrokoloid dipengaruhi oleh adanya kation atau anion karena ion yang ditambahkan ke dalam campuran hidrokoloid akan terjerembab ke dalam struktur ikatan hidrokoloid.

Pada pembuatan minuman berserat alami dari buah nanas dan nata de coco, terjadi blending antara sari nanas yang mengandung berbagai mineral dan senyawa aktif dengan nata de coco yang merupakan hidrokoloid. Saat dipasteurisasi, senyawa aktif dan mineral (ion-ion) akan berikatan dengan hidrokoloid sehingga campuran tersebut lebih stabil dan tahan lebih lama. Herawati (2018) menyatakan bahwa penambahan hidrokoloid mampu memperbaiki mutu produk pangan.

\section{Proses pasteurisasi dan sterilisasi kemasan}

Proses pasteurisasi bertujuan untuk membunuh mikroorganisme pembusuk (seperti khamir, kapang, dan bakteri) tanpa mengurangi kandungan gizi produk yang dipasteurisasi. Oleh karena itu pada saat pasteurisasi, campuran jus nanas dan nata de coco dipanaskan menggunakan api sedang (suhu $60-80^{\circ} \mathrm{C}$ ) selama $15-20$ menit agar kandungan gizi di dalam minuman tersebut tidak hilang. Pemanasan dengan suhu tinggi dan waktu pemanasan yang lama dapat menurunkan jumlah mikroba, kadar vitamin $C$, dan \% brix pada jus buah serta meningkatkan intensitas warna dan $\mathrm{pH}$ nya (Kusuma et al., 2007).

Produk minuman yang telah dipasteurisasi harus segera dikemas (di packing). Proses pengemasan sebaiknya dilakukan saat minuman berserat dalam keadaan hangat atau suamsuam kuku (suhu sekitar $45^{\circ} \mathrm{C}$ ).

Sebelum dilakukan proses pengemasan, terlebih dahulu dilakukan proses sterilisasi kemasan yang akan digunakan. Jenis kemasan yang digunakan berpengaruh terhadap masa simpan produk minuman tersebut. Kemasan botol kaca mampu mempertahankan kualitas minuman lebih lama dibandingkan dengan botol plastik. Hal ini dikarenakan proses sterilisasi botol kaca dapat dilakukan dengan pemanasan uap hingga suhu $100{ }^{\circ} \mathrm{C}$, sedangkan botol plastik hanya dapat disterilkan dengan cara membilas dan menggojoknya menggunakan air hangat (suhu < $60^{\circ} \mathrm{C}$ ) (Ismiyati dkk., 2018). 
JPPM (Jurnal Pendidikan dan Pemberdayaan Masyarakat), 7 (2), 2020 - 152

Aisyah Hadi Ramadani, Reny Rosalina, Riska Surya Ningrum

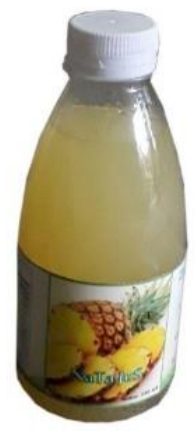

Gambar 2. Minuman berserat alami dari buah nanas dan nata de coco (dok. pribadi)

Proses pengemasan dilakukan dengan cara menuangkan minuman berserat ke dalam botol yang telah disterilisasi dan segera menutupnya dengan rapat. Hasil dari beberapa variasi cara pengemasan dan jenis kemasan yang digunakan pada proses pengemasan minuman berserat dapat dilihat pada Tabel 1.

Table 2. Variasi perlakuan pada proses pengemasan

\begin{tabular}{|c|c|c|}
\hline Jenis kemasan & Kondisi minuman & Hasil pengamatan \\
\hline Botol kaca & $\begin{array}{l}\text { Suam-suam kuku (suhu } 45 \\
\left.{ }^{\circ} \mathrm{C}\right)\end{array}$ & $\begin{array}{l}\text { Kualitas tetap terjaga hingga hari ke-21 pada } \\
\text { penyimpanan dingin (di dalam lemari es) }\end{array}$ \\
\hline Botol plastik & $\begin{array}{l}\text { Suam-suam kuku (suhu } 45 \\
{ }^{\circ} \mathrm{C} \text { ) }\end{array}$ & $\begin{array}{l}\text { Pada hari ke- } 6 \text { muncul kapang di permukaan dengan } \\
\text { diameter yang kecil }\end{array}$ \\
\hline Botol plastik & Dingin $\left(\right.$ suhu $\left.30^{\circ} \mathrm{C}\right)$ & $\begin{array}{l}\text { Pada hari ke- } 4 \text { muncul kapang di permukaan dengan } \\
\text { diameter yang besar }\end{array}$ \\
\hline Botol plastik & $\begin{array}{l}\text { Dingin }\left(\text { suhu } 30^{\circ} \mathrm{C}\right) \text { dan } \\
\text { ditambah-kan pengawet } \\
\text { alami }\end{array}$ & $\begin{array}{l}\text { Hingga hari ke } 21 \text { tidak muncul kapang pada } \\
\text { permukaan tetapi rasanya asam dan bergas. } \\
\text { Penyimpanan dilakukan di dalam lemari es. }\end{array}$ \\
\hline
\end{tabular}

Produk minuman berserat yang dihasilkan pada pelatihan ini juga memiliki life time. Umur simpan minuman yang pendek menyebabkan mitra tidak dapat memproduksi dalam jumlah yang banyak dalam sekali produksi. Kelemahan ini juga terjadi pada produk minuman sari buah apel "Dewata" sehingga tidak dapat memenuhi permintaan pasar pada moment tertentu (Mustaniroh et al., 2016). Produk yang tidak layak minum ditandai dengan munculnya bau asam saat kemasan dibuka, rasa yang kuat karena telah terjadi reaksi fermentasi, terbentuknya dua atau lebih lapisan, dan terbentuknya khamir atau kapang pada permukaan atas minuman.

Hasil perlakuan menunjukkan bahwa kemasan botol kaca memiliki daya tahan paling lama. Namun, biaya produksi pembelian botol kaca yang mahal menyebabkan kemasan ini tidak digunakan oleh masyarakat dusun Puhrejo. Masyarakat lebih memilih mengemas jus nata nanas ini dengan botol plastik yang kemudian diberi pengawet alami untuk diproduksi secara besar. Pemilihan kemasan yang marketable lebih lanjut akan mempengaruhi daya saing produk di pasar (Sugiyanto et al., 2017). Pernyataan tersebut dikuatkan oleh Sucipta et al. (2017) bahwa kemasan juga secara tidak langsung sebagai media promosi produk dan memperkuat branding merk. Faktor-faktor yang menjadi pertimbangan dalam pemilihan kemasan antara lain (1) keefektifan bahan dan desain dalam mengamankan produk dari kerusakan atau kontaminasi; (2) keekonomisan biaya kemasan dan mudah diperoleh; (3) fleksibilitas dalam distribusi sehingga mudah diangkut dan dipajang; (4) Komunikatif untuk menggambarkan produk; (5) Ergonomis ketika dibawa, dipegang, dibuka, dan disimpan; (6) Estetis pada pemaduan warna dan gambar; (7) Memiliki identitas yang unik sebagai pembeda dengan kemasan laiinya; (8) Awet dimana kemasan sendiri tidak cepat rusak. Produk minuman berserat yang dihasilkan dari pelatihan ini dapat dilihat pada Gambar 2. 
JPPM (Jurnal Pendidikan dan Pemberdayaan Masyarakat), 7 (2), 2020 - 153

Aisyah Hadi Ramadani, Reny Rosalina, Riska Surya Ningrum

\section{Pembuatan label dan pemasaran produk}

Pembuatan label produk minuman berserat dilakukan oleh karang taruna Dusun Puhrejo. Label yang dibuat dengan standar pelabelan yang diatur oleh PERKA BPOM No. 12 Tahun 2016 (Ernawanti, 2018) minimal memuat informasi sebagai berikut: (1) Nama produk, harus menarik, singkat, dan jelas; (2) Komposisi bahan; (3) Berat bersih; (4) Nomor ijin edar (PIRT); (5) Tanggal kadaluarsa; dan (6) Lokasi produksi/ lembaga produksi. Bentuk desain label yang telah dibuat tercantum pada Gambar 3.

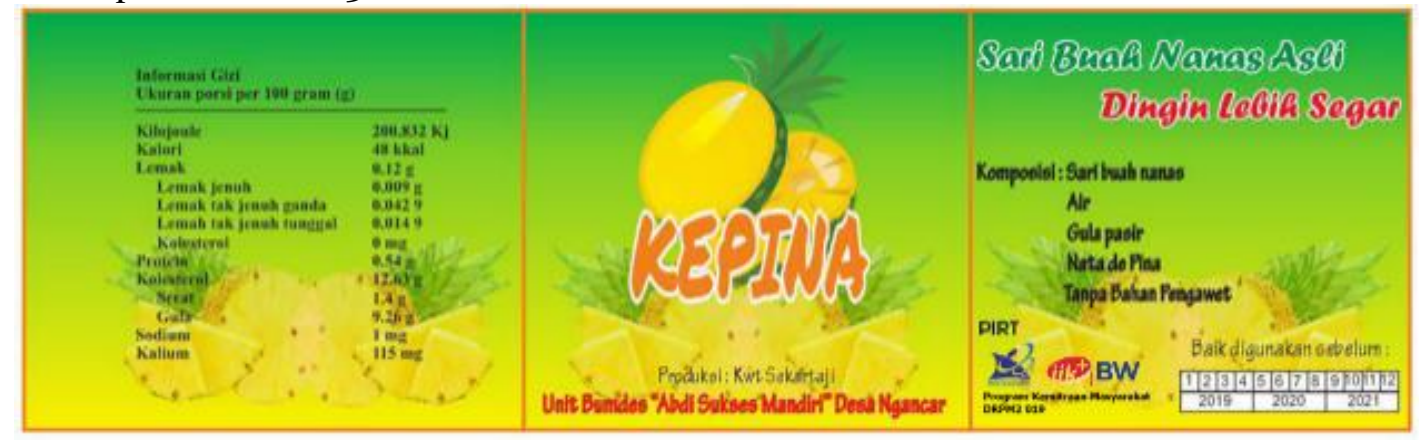

Gambar 3. Label produk jus nata nanas (dok. Pribadi)

Desain label harus dibuat informatif dan eye cathing karena mempengaruhi keputusan pembeli untuk membeli produk sebesar lebih dari 80\% (Huda \& Andrias, 2018; Iranita, 2013).

Sudahono dan Indrawati (2014) memperoleh fakta bahwa dari berbagai informasi yang tercantum pada label terdapat gradasi tingkat perhatian konsumen pada informasi tertentu. Urutan informasi paling segera dilirik oleh konsumen hingga paling tidak menarik adalah tanggal kadaluarsa, nama produk, logo halal, komposisi, berat bersih, petunjuk penyimpanan, nama produsen, dan terakhir nomor ijin edar. Hal serupa juga diungkap oleh Ernawati (2018) namun dengan perbedaan urutan informasi yang utama menurut konsumen hasil penelitiannya yaitu nama alamat produsen, berat bersih, nomor ijin edar, tanggal produksi, komposisi bahan, tanggal kadaluarsa, nama produk, dan terakhir logo halal.

Pada aspek pemasaran, tim pelaksana program memberikan materi sekilas mengenai jenis-jenis pemasaran kepada mitra. Terdapat 2 strategi pemasaran atau penjualan produk minuman berserat yang dapat dilakukan, yaitu pemasaran langsung (direct selling) dan pemasaran tidak langsung (indirect selling). Proses pemasaran langsung dapat dilakukan melalui tempat penjualan oleh-oleh khas Kediri yang ada di wilayah Ngancar atau di wilayah Kota Kediri dan instansi pemerintah (PemKab dan Kantor desa). Instansi pemerintah tersebut dapat membantu proses promosi produk dengan cara menggunakan produk minuman berserat sebagai jamuan saat menyambut tamu yang berkunjung. Pemerintah juga dapat berperan serta dengan cara mengikutsertakan produk minuman berserat yang dihasilkan pada acara pameran produk unggulan daerah. Dukungan yang baik dari pemerintah setempat akan menyehatkan partumbuhan UMKM yang baru dibentuk (Bohori, 2019). Akan tetapi pemasaran yang bergantung pada bantuan pemerintah ternyata berjalan terlalu pasif dan lambat. Untuk itu, masyarakat dusun Puherjo juga memasarkan peroduknya secara aktif melalui event-event pameran dengan memajang sekaligus menjual produk. Beberapa event pameran yang telah diikuti sebagai media promosi produk yaitu festival kelud, pameran produk desa yang diadakan oleh dinas koperasi, dan pameran halal di institute ilmu kesehatan bhakti wiyata Kediri. Pada ketiga acara tersebut jumlah penjualan produk jus nata nanas cukup baik.

Pemasaran tidak langsung dapat dilakukan melalui media sosial seperti instagram, facebook, dan tokopedia. Akun media sosial dikelola oleh karang taruna Dusun Puhrejo. Namun, pemasaran dengan online masih mengalami kendala dari aspek fasilitas teknologi seperti kurang mendukungnya jaringan internet di kawasan dusun Puhrejo. Pemasaran yang dipilih akan mempengaruhi tingkat penjualan dan omset yang diperoleh oleh penjual (Khairani \& Pratiwi, 2018). 
JPPM (Jurnal Pendidikan dan Pemberdayaan Masyarakat), 7 (2), 2020 - 154

Aisyah Hadi Ramadani, Reny Rosalina, Riska Surya Ningrum

\section{Analisis tekno ekonomi}

Proses produksi dan pemasaran produk minuman berserat yang nantinya dilanjutkan oleh UMKM Dusun Puhrejo tentunya membutuhkan analisis tekno ekonomi untuk mengetahui besarnya modal yang dibutuhkan, harga produk yang dihasilkan, dan laba yang dapat diperoleh. Oleh karena itu, pada kegiatan pelatihan pembuatan jus nanas dengan penambahan nata de coco ini juga diberikan pengetahuan kepada peserta mengenai analisis tekno ekonominya, yang dapat dilihat pada Tabel 2.

Berdasarkan data yang tertera pada table 2, dapat diketahui bahwa modal yang diperlukan untuk memproduksi 53 botol minuman berserat dari buah nanas dan nata de coco adalah Rp. 204.00o. Jika setiap botolnya dijual dengan harga Rp. 5000 maka keuntungan yang diperoleh adalah Rp. 1.150 per botol atau total keuntungan yang diperoleh adalah Rp.6o.950.

\section{Perijinan produk (PIRT)}

Legalitas ijin edar suatu produk akan memperkuat posisi daya saing produk dengan produk yang sejenis. Ijin edar menggambarkan bahwa produk telah layak dan aman untuk dikonsumsi oleh masyarakat luas. Pada pelatihan ini diberikan pendampingan untuk persiapan pengajuan ijin edar produk jus nata nanas kepada dinas kesehatan yang juga dipandu oleh dinas koperasi Kabupaten Kediri.

Table 3. Perhitungan tekno ekonomi

\begin{tabular}{lcccc}
\hline \multicolumn{1}{c}{ Bahan } & Keperluan & Satuan & Harga satuan & Harga total (ribu rupiah) \\
\hline buah nanas & 3 & $\mathrm{Kg}$ & 10 & 30 \\
nata de coco & 1 & $\mathrm{Kg}$ & 8 & 8 \\
gula pasir & 1,5 & $\mathrm{Kg}$ & 15 & 22,5 \\
air mineral & $\mathrm{O}, 5$ & galon & 8 & 4 \\
botol plastik 350 ml & 53 & $\mathrm{pcs}$ & 1,5 & 79,5 \\
label & 4 & $\mathrm{~A} 3$ & 10 & 40 \\
LPG 3 Kg & 1 & tabung & 20 & 20 \\
& & Total biaya yang dibutuhkan & 204 \\
& & Biaya satuan & 3,849 \\
& & Harga jual satuan & 5 \\
& & Laba per botol & 1,151 \\
\hline
\end{tabular}

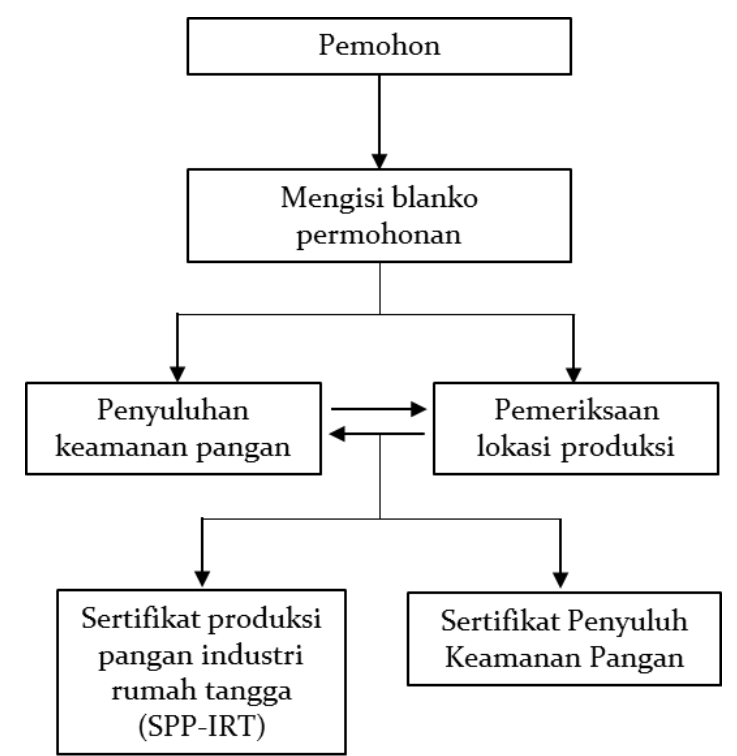

Gambar 4. Skema alur pengajuan P-IRT Dinas Kesehatan Kabupaten Kediri

(Dinas Kesehatan Kabupaten Kediri, 2014) 
JPPM (Jurnal Pendidikan dan Pemberdayaan Masyarakat), 7 (2), 2020 - 155

Aisyah Hadi Ramadani, Reny Rosalina, Riska Surya Ningrum

Tahapan untuk pegajuan ijin edar antara lain: (1) Prapendaftaran P-IRT yang meliputi persiapan sarana produksi yang layak, pemberian pelatihan cara produksi pangan yang baik sesuai standar P-IRT, pelatihan desain label dan kemasan, dan pembuatan prototype produk jus nata nanas; (2) Pendaftaran produk; (3) Penyuluhan keamanan pangan; (4) Inspeksi sarana produksi; (5) Pemberian nomor P-IRT dan sertifikat ijin edar. Skema alur pengajuan P-IRT yang berlaku di kabupaten Kediri (Dinas Kesehatan Kabupaten Kediri, 2014) tertera pada gambar 4.

Ernawanti (2018) menyebutkan bahwa nomer P-IRT yang tertera pada label kemasan adalah informasi ketiga yang dilihat oleh konsumen setelah nama produk dan berat bersih saat meninjau lebih detail suatu produk. Pada pelatihan ini tim pelaksana memfokuskan pendampingan pada tahap prapendaftaran. Kelompok mitra diberi fasilitas sarana produksi seperti botol kemasan, label, pansi, blender, pengaduk, water container dengan kran dan thermometer. Kegiatan pelatihan pembuatan produk, pengemasan, dan pelabelan hingga prototype telah dijelaskan di subpembahasan sebelumnya.

Tahapan pendaftaran produk selanjutnya difasilitasi oleh pihak desa. Tahap penyuluhan keamanan pangan untuk produk jus nata nanas ini tidak diselenggarakan karena menggunakan sertifikat penyuluh keamanan pangan yang dimiliki oleh kepada dusun Puhrejo. Proses pemberian nomor P-IRT ini mengalami kendala penundaan akibat antrian inspeksi sarana produksi yang membutuhkan waktu lama. Namun, mitra memiliki semangat yang baik untuk terus mengawal pengajuan P-IRT.

\section{Analisis ketercapaian target kegiatan}

Kegiatan pelatihan pembuatan jus nanas dengan penambahan nata de coco yang dilaksanakan di Dusun Puhrejo berlangsung dengan baik dan lancar. Antusiasme peserta juga relatif tinggi, terlihat dari keaktifan peserta dalam bertanya dan menanggapi materi yang diberikan oleh pemateri. Selain itu, peserta juga berperan aktif ketika sesi pelatihan diberikan.

Ketercapaian target kegiatan diukur dengan cara memberikan kuisioner kepada peserta sebelum dan setelah kegiatan pelatihan dilaksanakan. Pengukuran dilakukan untuk mengetahui dampak pelatihan terhadap peningkatan pengetahuan peserta, peningkatan minat peserta dalam mengembangkan produk olahan nanas, dan kebermanfaatan yang dirasakan oleh peserta atas terlaksananya kegiatan ini. Kuisioner yang diberikan kepada peserta memuat beberapa pertanyaan yang berkaitan dengan kandungan, manfaat, dan cara pengolahan produk olahan nanas. Jawaban yang diberikan oleh peserta akan diberi skor, dimana total skor yang diperoleh dapat menunjukkan pengetahuan yang dimiliki oleh peserta terkait tentang pemanfaatan dan pengolahan nanas. Akumulasi dari skor tersebut dikategorikan menjadi 3 macam, yaitu rendah, sedang, dan tinggi. Hasil kuisioner tercantum pada Gambar 4.

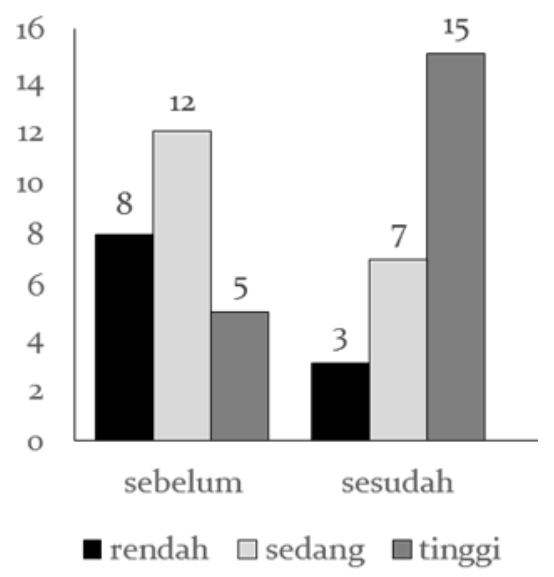

Gambar 4. Tingkat pengetahuan peserta pelatihan mengenai pemanfaatan dan pengolahan nanas

Selain dapat meningkatkan pengetahuan peserta mengenai pemanfaatan dan pengolahan nanas, kegiatan ini juga mampu membangkitkan semangat peserta untuk mengembangkan dan 
JPPM (Jurnal Pendidikan dan Pemberdayaan Masyarakat), 7 (2), 2020 - 156

Aisyah Hadi Ramadani, Reny Rosalina, Riska Surya Ningrum

mempromosikan produk olahan buah nanas demi meningkatkan nilai jualnya. Hasil evaluasi pada diagram lingkaran Gambar 5 juga menunjukkan bahwa menurut peserta pelatihan, kegiatan pelatihan ini sangat bermanfaat. Ke depan, produk yang dihasilkan dari pelatihan ini akan dikembangkan oleh UMKM Dusun Puhrejo dan didaftarkan izin edarnya (PIRT) sehingga dapat dijadikan sebagai salah satu produk unggulan UMKM Dusun Puhrejo.

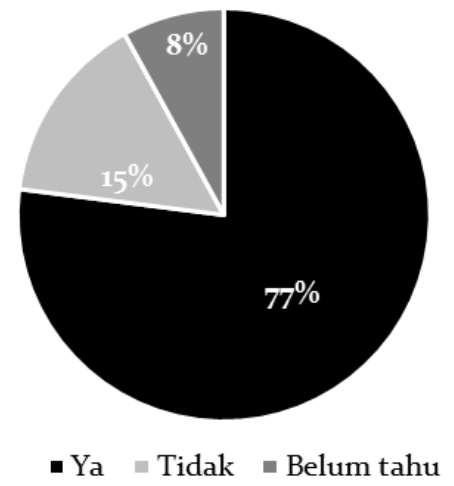

Gambar 5. Respon peserta terhadap minat untuk mengembangkan produk olahan nanas

Keberlanjutan program kemitraan masyarakat yang didanai oleh Kemenristekdikti semacam ini perlu terus dikawal dan dievaluasi. Kurniawan et al. (2019) kejelasan terkait adanya pelatihan atau pendampingan lanjutan sangat menentukan efektivitas program yang dibuat.

\section{SIMPULAN}

Kegiatan pelatihan ini mampu meningkatkan pengetahuan dan minat masyarakat dalam mengolah dan mengembangkan produk berbahan dasar buah nanas. Produk olahan nanas ini dapat meningkatkan nilai jual buah nanas, menjadi produk unggulan UMKM Dusun Puhrejo dan mewujudkan kemandirian ekonomi masyarakat, khususnya Dusun Puhrejo.

\section{DAFTAR PUSTAKA}

Anam, C., Zaman, M. Z., \& Khoirunnisa, U. (2019). Mengungkap senyawa pada nata de coco sebagai pangan fungsional. Jurnal Ilmu Pangan Dan Hasil Pertanian, 3(1), 42-53.

Andjaitan, M., Hendardi Pamudja, K., Idris, F., Tjandra, M., \& Wiriantono, T. (2018). Bromelain Enzyme from pineapple fruit as an antiviral agent against HIV, Hepatitis $\mathrm{C}$ and Human Papiloma Virus. Journal of Engineering and Applied Sciences, 13, 3125-3130. https://doi.org/10.36478/jeasci.2018.3125.3130

Bhagavanthy S, Gayathridevi R, Pushya K, \& Jeniffer J. (2019). Screening, optimization and antimicrobial activity of Bromelain from Ananas comosus. International Journal of Scientific Development and Research (IJSDR), 4(8), 233-240.

Bohori, M. (2019). Peran dinas koperasi dalam pengembangan UMKM Unggulan di Surabaya. Universitas Islam Negeri Sunan Ampel Surabaya.

BPS. (2014). Kabupaten Kediri Dalam Angka 2014. BPS Kabupaten Kediri.

BPS. (2015). Statistik tanaman buah-buahan dan sayuran tahunan Indonesia. BPS-Statistics Indonesia.

Dinas Kesehatan Kabupaten Kediri, -. (2014). Pelayanan publik bidang kesehatan Dinas Kesehatan Kabupaten Kediri.

Dinas Pertanian Kabupaten Kediri. (2015). Nanas (Issue September, pp. 1-2).

Ernawanti, E. (2018). Pemenuhan persyaratan label produk pangan yang dijual secara online terhadap peraturan label pangan. Institut Pertanian Bogor.

Halib, N., Amin, M. C. I. M., \& Ahmad, I. (2012). Physicochemical properties and characterization of nata de coco from local food industries as a source of cellulose. Sains 
JPPM (Jurnal Pendidikan dan Pemberdayaan Masyarakat), 7 (2), 2020 - 157

Aisyah Hadi Ramadani, Reny Rosalina, Riska Surya Ningrum

Malaysiana, 41(2), 205-211.

Harianti, R., \& Tanberika, F. S. (2018). Pemberdayaan wanita tani melalui produksi abon ikan lele. JPPM (Jurnal Pendidikan Dan Pemberdayaan Masyarakat), 5(2), 167-180. https://doi.org/10.21831/jppm.v5i2.21071

Herawati, H. (2018). Potensi hidrokoloid sebagai bahan tambahan pada produk pangan dan nonpangan bermutu. Jurnal Litbang Pertanian, 37(1), 17-25. https://doi.org/10.21082/jp3.v37n1.2018.p17-25

Hossain, F., Akhtar, S., \& Anwar, M. (2015). Nutritional value and medicinal benefits of pineapple. International Journal of Nutrition and Food Sciences, 4(1), 84-88. https://doi.org/10.11648/j.ijnfs.20150401.22

Huda, Q. A., \& Andrias, D. R. (2018). Sikap dan perilaku membaca informasi gizi pada label pangan serta pemilihan pangan kemasan. Media Gizi Indonesia, 11(2), 175. https://doi.org/10.20473/mgi.v11i2.175-181

Iranita. (2013). Pengaruh labelisasi halal terhadap keputusan pembelian pada Mahasiswa Fakultas Ekonomi Universitas Maritim Raja Ali Haji.

Ismiyati, Nugrahani, R. A., \& Hendrawati, T. Y. (2018). Diversifikasi menjadi produk selai dan peningkatan mutu jus aloe vera di SIGMA Food Sawangan Depok. Jurnal Pengabdian Kepada Masyarakat, 3(2), 188-195.

Jenitha X, A., \& Anusuya A. (2016). Phytochemical screening and in vitro antioxidant activity of ananas comosus. International Journal of Research in Pharmacology $\mathcal{E}$ Pharmacotherapeutics, 5(2), 162-169. https://ijrpp.com/ijrpp/article/view/345

Kaushik, J., \& Kundu, N. (2018). Phytochemical screening, anti-oxidant and anti-microbial activity of polyphenolic flavonoids isolated from fruit of ananas comosus in various solvents. International Journal of Scientific and Research Publications, 8(2), 31.

Kemmis, S., \& Mc Taggart, R. (1988). The action research planner. Deakin University Press.

Khairani, S., \& Pratiwi, R. (2018). Peningkatan omset penjualan melalui diversifikasi produk dan strategi promosi pada UMKM kerajinan souvenir Khas Palembang. CARADDE: Jurnal Pengabdian Kepada Masyarakat, 1(1), 36-43.

https://doi.org/10.3196o/caradde.vii1.18

Kurnia, T. W., Iskandar, A., \& Hernawan, D. (2019). Efektivitas program pelatihan keterampilan berbasis masyarakat (KK miskin) oleh Dinas Tenaga Kerja dan Transmigrasi Kota Bogor. JURNAL SOSIAL HUMANIORA, 10(1), 1. https://doi.org/10.30997/jsh.v1oi1.1714

Kusuma, H. R., Ingewati, T., Indraswati, N., \& Martina. (2007). Pengaruh Pasteurisasi terhadap kualitas jus jeruk Pacitan. Widya Teknik, 6(2), 142-151.

Mustaniroh, S. A., Rofiatul Chasnaq, C., \& Santoso, I. (2016). Marketing strategic planning of "dewata" apple beverages using quantitative strategic planning matrix method. Industria: Jurnal Teknologi Dan Manajemen Agroindustri, 5(1), 21-29. https://doi.org/10.21776/ub.industria.2016.005.01.3

Nugroho, R. (2017). Keberdayaan perempuan pasca pelatihan mengolah sampah bagi kelompok pemberdayaan dan kesejahteraan keluarga. JPPM (Jurnal Pendidikan Dan Pemberdayaan Masyarakat), 4(2), 146-156. https://doi.org/10.21831/jppm.v4i2.16225

Rahmat, A., \& Mirnawati, M. (2020). Model Participation action research dalam pemberdayaan masyarakat. AKSARA: Jurnal Ilmu Pendidikan Nonformal, o6(o1), 62-71.

Ramadani, A. H., Rosalina, R., \& Suryaningrum, R. (2019). Inisiasi pengolahan nanas terpadu sebagai upaya peningkatan nilai jual sumber daya lokal dusun puhrejo kabupaten kediri. Prosiding Seminar Nasional SIMBIOSIS IV, 59-63.

Santosa, B., Wignyanto, W., Hidayat, N., \& Sucipto, S. (2020). The quality of nata de coco from 
JPPM (Jurnal Pendidikan dan Pemberdayaan Masyarakat), 7 (2), 2020 - 158

Aisyah Hadi Ramadani, Reny Rosalina, Riska Surya Ningrum

sawarna and mapanget coconut varieties to the. Food Research, 1-7.

Saugi, W., \& Sumarno, S. (2015). Pemberdayaan perempuan melalui pelatihan pengolahan bahan pangan lokal. JPPM (Jurnal Pendidikan Dan Pemberdayaan Masyarakat), 2(2), 226238. https://doi.org/10.21831/jppm.v2i2.6361

Setiaji, B., Setyopratiwi, A., \& Cahyandaru, N. (2010). Exploiting a benefit of coconut milk skim in coconut oil process as nata de coco substrate. Indonesian Journal of Chemistry, 2(3), 167-172. https://doi.org/10.22146/ijc.21912

Sucipta, I. N., Suriasih, K., \& Kenacana, P. K. D. (2017). Pengemasan pangan. Kajian pengemasan yang aman, nyaman, efektif dan efisien. Udayana University Press.

Sudahono, N., \& Indrawati, Y. M. (2014). Gambaran perilaku membaca label pangan dan pengetahuan gizi pada mahasiswa jenjang sarjana reguler FKM UI angkatan 2013. Universitas Indonesia.

Sugiyanto, S., Karima, A., \& Yogananti, A. F. (2017). Peningkatan ketrampilan pembuatan desain kemasan serta pemanfaatan media promosi dan pemasaran online pada Kube Ash-Shidiqqy dan Pik Abdussalam Jepara. Techno.Com, 16(1), 9-16. https://doi.org/10.33633/tc.v16i1.1283

Sukara, E., \& Meliawati, R. (2014). Potential values of BacteriaL Cellulose for industrial applications. Jurnal Selulosa, 4(1), 7-16. 